\title{
Reconstruction Of The Execution Regulation Of Administrative Court Decision In Legal Protection Principle Perspective
}

\author{
Syofyan Hadi ${ }^{1}$, Sudarsono ${ }^{2}$, Istislam ${ }^{3}$, Moh. Fadli ${ }^{4}$ \\ ${ }^{1}$ Student of Doctor of Law Study Program Faculty of Law Brawijaya University \\ ${ }^{2}$ Professor of Administrative Law at Faculty of Law Brawijaya University \\ ${ }^{3}$ Associate Professor at Faculty of Law Brawijaya University \\ ${ }^{4}$ Associate Professor at Faculty of Law Brawijaya University \\ ${ }^{5}$ Mukti Fajar, Tipe Negara Hukum, (Malang: Bayumedia Publishing, 2005), p. 42 \\ ${ }^{6}$ Paulus Effendi Lotulung, Lintasan Sejarah dan Gerak Dinamika Peradilan Tata Usaha Negara (PERATUN) Di Mata Paulus Effendi Lotulung,
} (Jakarta: Salemba Humanika, 2013), p. 72.

DOI: $10.29322 /$ IJSRP.10.03.2020.p9916

http://dx.doi.org/10.29322/IJSRP.10.03.2020.p9916

\begin{abstract}
The establishment of Administrative Court aims to provide legal protection for the people from government actions that are not in accordance with the law. However, the existence of Administrative Court does not fully provide legal protection due to the difficulty of executing of Administrative Court decisions that have permanent legal force. Therefore, it is necessary to reconstruct the execution regulation in Article 116 of Law Number 51 Year 2009. The reconstruction is based on the principle of legal protection for the people. Based on these principles, execution is a people's right which must be guaranteed by government officials. In the reconstruction, it is necessary to regulate coercive measures, regulation for adequate compensation, and institutions of execution.
\end{abstract}

Index Terms- Execution, Decision, Administrative Court, Reconstruction.

\section{PRELEMINARY}

$\mathrm{T}^{\mathrm{k}}$ he establishment of the Administrative Court cannot be separated from the ideals of the rule of law. Administrative Court is one of the characteristics of the rule of law. ${ }^{1}$ In rule of law, Administrative Court is intended to provide legal protection to the people from government actions. In this regard, Paulus Effendi Lotulung said that the establishment of Administrative Court is to resolve disputes between the government and its citizens as a result of government actions that were considered violating the rights of citizens with the aim of providing legal protection to the people (both individual rights and community rights). ${ }^{2}$

Administrative Court is a court to question or to review the actions of the government that violate citizen's right. In practice, not a few government actions that contrary to the law are canceled

${ }^{1}$ Mukti Fajar, Tipe Negara Hukum, (Malang: Bayumedia Publishing, 2005), p. 42 by the Administrative Court. But in practice too, the Administrative Court decision is very difficult to execute. This is due to the weakness of regulation regarding the execution of Administrative Court decisions in Article 116 of Law Number 51 Year 2009. In other words, these provisions are not effective in providing guarantees of the execution of the Administrative Court decision. It can be seen that there are still many Administrative Court decisions that are not executed, for example (1) Verdict Number 127/G/2017/PTUN.SBY juncto Decision Number 108/B/2010/PT.TUN.SBY between Ratna Endang Hartatiek T vs. Mayor of Surabaya, (2) Decision Number 18/P/FP/2018/PTUN.SBY between Saroni vs Head of Kepuh Village, Papar District of Kediri Regency, and (3) Decision Number 17/P/FP/2018/ PTUN.SBY between Muhammad Zainul Irsyadi vs. Head Kepuh Village, Papar District, Kediri Regency. These decisions were not executed by government officials. Therefore, this paper proposes the reconstruction of the execution regulation of Administrative Court's decision in legal protection principle perspective.

\section{FORMULATION PROBLEM}

How is the reconstruction of the execution regulation of Administrative Court decisions in legal protection principle perspective?

\section{METHOD RESEARCH}

This research is a legal research using a statutory, conceptual and philosophical approach. The legal materials used are primary, secondary, and tertiary which are analyzed using normative/prescriptive analysis.

2 Paulus Effendi Lotulung, Lintasan Sejarah dan Gerak Dinamika Peradilan Tata Usaha Negara (PERATUN) Di Mata Paulus Effendi Lotulung, (Jakarta: Salemba Humanika, 2013), p. 72. 


\section{ANALYSIS}

\section{Problems in the Execution Regulation of Execution of} Administrative Court Decisions

The law was established to be a guideline for the government to act and limit its actions, and at the same time as a protector/save guard for the people from the government arbitrariness. Even though the law has provided restrictions on government actions, but there are always government actions contrary with the law (onrechtmatig). Therefore, in the rule of law, the people are guaranteed legal protection i.e the right to submit a review of government actions to court (judicial review). In this regard, Juli Ponce said that "...where statute ends, tyranny begins-and the only effective protection against tyranny is judicial review. Therefore, traditional administrative law is not especially interested in good administrative decisions but in the judicial review of illegal decisions, to protect citizens against public arbitrariness...". 3

In order to provide legal protection, Administrative Court was established as one of the executor of judicial power. The existence of the Administrative Court is closely related to the principle of the rule of law guaranteed in Article 1 paragraph (3) of the Constitution of the Republic of Indonesia Year 1945 and the effort to provide legal protection to the people. The people are given the right to review government decisions. However, the principle of legal protection has a meaning if there is a guarantee that the government executes Administrative Court decision that have permanent legal force. The guarantee of the execution of the Administrative Court decision is not included in Article 116 of Law Number 51 Year 2009, so that the Administrative Court decision is very difficult to execute. Therefore, the existence of Administrative Court is not fully as an instrument of legal protection to the people. This condition certainly raises legal uncertainty in the implementation of government and development. $^{4}$

According to the author there are some weaknesses in the regulation of the execution of Administrative Court decision in Article 116 of Law Number 51 Year 2009, namely as follows:

a. Article 116 of Law Number 51 Year 200 gives an authority of Government to execute Administrative Court decisions themselves, so that there are no executing institutions as in the case of criminal and civil court decisions.

b. The time to declare an invalid administrative decision does not have legal force in Article 116 paragraph (2) and paragraph (3) is too long.

c. The time to declare an invalid administrative decision does not have legal force in Article 116 paragraph (2) and paragraph (3) is too long.

d. There are no implementing regulations regarding the imposition of coercive measures, specifically regarding the about coercive fines ( $d$ wangsom)

e. The regulation regarding the submission of a report on the non-executing of an Administrative Court decision to the President and to a representative body in article 116 paragraph (4) is not compelling because it is not

3 Juli Ponce, Good Administration and Administrative Procedure, (Indiana Journal of Global Legal Studies, Volume 12 Issue 2, 2005), p. 554. accompanied by legal consequences if it is not implemented.

f. The absence of criminal sanctions for government officials who do not carry out Administrative Court decisions.

Reconstruction of Execution Regulation of Administrative Court Decision in the Perspective of Legal Protection Principles

Weakness in the regulation of Article 116 of Law Number 51 Year 2009 causes there are Administrative Court decisions is not executed by government officials. That condition has negative legal implications for legal protection for the people. Therefore, the execution regulation in Article 116 of Law Number 51 Year 2009 need to be reconstructed. The reconstruction is based on the principle of legal protection as the main legal principle with the following characteristics:

1. The execution of the Administrative Court decision is a right for the people given by the Administrative Court decision. Therefore, repressive legal protection must be redefined, so that it contains the right of people who have been harmed by the actions/decisions of government officials, to sue the people to Administrative Court and the right of execution for the people whose claim was granted by the Administrative Court decision.

2. Execution regulation of Administrative Court decision must be based on legal principles aimed at upholding the principles of legal protection for the people, such as the principle of res judicata pro veritate habetur, the principle, the principle of justice, and the principle of legal certainty.

3. Execution regulation of Administrative Court decision must be in accordance with the principles of forming legislation such as the principle of clear norm formulation, the principle of consistency, and the principle can be implemented.

4. Execution regulation of Administrative Court decisions must be regulated to provide guarantees to people to obtain their rights and guarantee that government officials will carry out what is required by Administrative Court decisions. Therefore, regulation regarding coercive measures are urgently needed, including the imposition of criminal sanctions as ultimum remedium.

5. Regulation regarding the provision of adequate and fair compensation in accordance with the losses suffered by people.

Based on these five concepts, the reconstruction of the execution regulation of Administrative Court includes the following matters: (1) The legal strength of the administrative decision that was canceled by the Administrative Court; (2) Models of automatic execution and non-automatic execution; (3) The timeframe for the head of the court to order the government official to execute; (4) Imposition of coercive measures i.e coercive fines and/or administrative sanctions; (5) Announcement in the local print mass media; (6) Reporting to the President; (7)

4 Supandi, Kepatuhan Pejabat Dalam Menaati Putusan Pengadilan Tata Usaha Negara, (Medan: Disertasi Program Pascasarjana Universitas Sumatera Utara, 2005), p. 266. 
Amount of compensation; (8) Guarantees for the people to obtain executions after coercive measures were made; (9) Model of execution of Administrative Court decisions whose authority is regulated in Law Number 30 Year 2014; (10) The need for criminal sanctions; and (11) An execution agency should be formed in certain cases. The results of the reconstruction are as follows:

1. The canceled administrative decision has no binding legal force since inkracht of Administrative Court decision.

The canceled administrative decision has no binding legal force since the Administrative Court decision has permanent legal binding (inkracht van gewijsde). Administrative Court's decision that inkracht van gewijsde has binding legal force. Supposedly, an administrative decision that was canceled has no binding legal force since the decision of the Administrative Court is inkracht.

2. Obligations for government officials to execute Administrative Court decisions in Article 97 paragraph (9) letter a, letter b, and letter c, paragraph (10) and paragraph (11) within a period of 10 days

There is no more automatic execution, so all Administrative Court decisions that require/punish government officials must be executed. In addition, the time period is shortened to 10 days to provide legal protection for the people.

3. The chairman of the court must order the government official to execute after the plaintiff submits the application no later than 5 days

To provide legal certainty as a characteristic of the theory of the rule of law in a formal aspect, it is necessary to provide a period of time.

4. Government officials who do not execute Administrative Court decisions in Article 97 paragraph (9) letter a, letter b, and letter c, paragraph (10) and paragraph (11) are subject to coercive measures i.e dwangsom and/or administrative sanctions. The coercive measures was imposed on the person of the official

Imposition of dwangsom (coercive fines) not to government agencies, but personally to officials who do not carry out Administrative Court decisions. This is very closely related to the official fault (faute de personele), not function's fault (faute de service), because the non-execution of the Administrative Court decision was caused by the personal mistake of the official concerned. The non-execution of an administrative court decision by a government official can be categorized as an act of maladministration as determined in Article 1 number 3 of Law Number 37 Year 2008 namely to ignore or neglect its legal obligations. On the one hand, if $d$ wangsom is applied to officials personally, it will facilitate its execution, because if $d$ wangsom is charged to government agencies it will cause its own problems, because payments must be in accordance with state financial management procedures.

5. The coercive fines determined in the decision by amount of Rp. 100,000,-.

In the dictum of decision, the Administrative Court also imposed a cutting of official salary as guarantee of coercive fines payment. In addition, the provisions of coercive fines in the Civil Procedure Code apply automatically (mutatis mutandis).
6. Forms of administrative sanctions, authorized officials, and sanctions for officials who do not apply administrative sanctions.

The form of administrative sanctions for government officials are (a) Temporary termination by obtaining office rights; (b) Temporary termination without obtaining office rights; and/or (c) Permanent termination from office without obtaining office rights. In addition, officials who do not impose sanctions are also given sanctions.

7. Announcement on print media, online mass media, Administrative Court website or website of representative institutions

To ensuring the execution of Administrative Court decision, announcements are not only limited to print media, but also need to make announcements online that can be accessed by everyone on the Administrative Court website, the representative body website, and etc.

8. The President must follow up on the report of the Head of the court within 10 days. In addition, there are sanctions for officials who do not carry out the President's order

Regulation regarding the time period for the President to follow up on the report of the head of the Administrative Court are very necessary, so that it does not depend solely on the President's judgment. In addition, it is necessary to impose sanctions for the President if he does not carry out his obligations or there are also sanctions for officials who do not carry out the President's order.

9. The higher-ranking official is obliged to execute the Administrative Court decision if the official still does not execute even though all forced efforts have been made.

It is intended that the execution of the Administrative Court decision has an edge. Thus, justice and legal certainty for the people will be guaranteed.

10. The enactment, automatically (mutatis mutandis), of the regulation of the execution of Administrative Court decision in this Law and the provisions in the Civil Procedure Code of the Administrative Court authority regulated in Law Number 30 Year 2014

11. Compensation is determined according to factual conditions by Administrative Court. The government is also required to budget compensation in the budget planning, both in state budget planning and local budget planning.

12. Optimizing the role of bailiffs as an execution agency for the execution of Administrative Court decisions related to compensation, coercive fines (dwangsom), and unlawful acts by the government.

\section{CONCLUSION}

The execution of Administrative Court decision has been regulated in Article 116 of Law Number 51 Year 2009. However, the article has weaknesses, the execution time is too long, there is no mechanism for applying coercive measures, and other weaknesses. This makes, the Administrative Court decision is very difficult to execute, so it is not in accordance with the principles of legal protection. Therefore, the article needs to be reconstructed based on the principle of legal protection, where the execution is 
a people's right which must be guaranteed by government officials. The results of the reconstruction of execution regulation are decisions that are null and void since the decision was inkracht, the obligation of government officials to execute all condemnatoir decisions for 10 days, the obligation for the head of court to order officials to execute decisions within 5 days, coercive fines and/or administrative sanctions handed down to officials personally, announcements not only in print media, but also in online media, the obligation for the President to order officials to execute within 10 days, executions by higher officials in the event that all coercive measures have been made, the determination loss based on the amount of loss, and optimize the role of the bailiff as an executing agency in the case of compensation, dwangsom, and unlawful acts by the government.

\section{REFERENCES}

[1] Fajar, A. Mukti. (2005). Tipe negara Hukum. Malang: Bayumedia Publishing.
[2] Lotulung, Paulus Efendi. (2013). Lintasan Sejarah dan Gerak Dinamika Peradilan Tata Usaha Negara (PERATUN) Di Mata Paulus Effendi Lotulung. Jakarta: Salemba Humanika.

[3] Ponce, Juli. (2005). Good Administration and Administrative Procedure. Indiana Journal of Global Legal Studies, Volume 12 Issue 2.

[4] Supandi. (2005). Kepatuhan Pejabat pemerintah Dalam Menaati Putusan Pengadilan Tata Usaha Negara. Disertasi Program Pascasarjana Universitas Sumatera Utara, Medan.

\section{AUTHORS}

First Author - Syofyan Hadi, Student of Doctor of Law Study Program Faculty of Law Brawijaya University

Second Author - Sudarsono, Professor of Administrative Law at Faculty of Law Brawijaya University

Third Author - Istislam, Associate Professor at Faculty of Law Brawijaya University

Fourth Author - Moh. Fadli, Associate Professor at Faculty of Law Brawijaya University 